\title{
Individual-Level Explanations of Corruption Within an Intercollegiate Context
}

\author{
Lisa Kihl \\ University of Minnesota
}

\begin{abstract}
Understanding why individuals engage in sport corruption is an emerging topic of research. Micro-level accounts of corruption have generally used a single disciplinary approach toward understanding why actors commit corruption (e.g., doping and match-fixing) in specific sports. The purpose of this study was to first examine individual-level explanations of corruption in the context of intercollegiate athletics; and, second, to generate an interdisciplinary framework. A multi-case analysis was conducted of 20 National Collegiate Athletic Association (NCAA) major infractions (corruption) reports that occurred between 2005 and 2015. The findings showed that actors' explanations were based on psychological factors - motivations (social relationship and self-interest) and personal norms, professional factors (abuse of power and failure of responsibilities), and justification factors (rationalizing strategies). This research builds on existing scholarship by generating an interdisciplinary framework of micro-level accounts of sport corruption in intercollegiate athletics.
\end{abstract}

Keywords: causes sport corruption, micro-level accounts, rule violations, interdisciplinary corruption framework

The engagement of corrupt acts, by individual sport actors and renegade groups is one of the principle threats to the integrity of the sport industry. Causes of corruption in college sports have been extensively discussed (e.g., Lopiano, 2016; Nixon, 2014; Yost, 2009; Zimbalist, 2018), yet are under-theorized and limited empirical research has examined micro-level (individual) explanations of sport corruption occurring across National Collegiate Athletic Association (NCAA) sports. Intercollegiate athletic sport corruption ranges from significant/severe breach of conduct and/ or major infractions to incidental issues/breaches of conduct (secondary violations) committed by individuals (e.g., athletes, coaches, administrators, staff, faculty, organizational representatives) and/or referent groups (e.g., coaches, apparel representatives, agents) (NCAA, 2016). From 2005to 2015, the NCAA reported 126 major/ severe infractions cases that involved three different forms of corruption (i.e., fraud, bribery and unethical conduct) and their respective types (e.g., academic, impermissible inducements, knowingly influencing others to furnish false or misleading information) (NCAA, 2016). Albeit minimal, research on the engagement of intercollegiate athletic corruption has focused almost exclusively on meso-level (i.e., program and/or institutional) explanations (e.g., university characteristics, and lead- 
ership, conference rivals, pressure to win) in the context of revenue sports (football and men's basketball) (e.g., Clark \& Batista, 2009; Fizel \& Brown, 2014). However, this research does not offer micro-level explanations of the persons (e.g., athletes, coaches, administrators, staff or organizational representatives) and their collective groups who actually engage in corrupt acts. Given the NCAA's extensive compliance system, research should focus on examining "contextual determinants of corruption and interactional processes whereby people come to develop and/or share corrupt-favorable acts" (Zaloznaya, 2014, p. 193). To contribute to our understanding of factors that contribute to corrupt behavior, requires more contextually-based research on corruption (De Graff, 2009; Pertiwi, 2018), "for which we need a theoretical model" (De Graff, 2009, p. 42). This research aims to respond to these scholars' calls by examining individuals' explanations of engaging in corrupt acts within the context of intercollegiate sports.

In the broader sport corruption literature the individual explanations of corruption have drawn from different academic disciplines including economics, sociology, criminology, and psychology where the vast majority has focused on explanations within the context of understanding how and why match fixing (e.g., Bag \& Saha, 2011; Hill, 2009a; Manoli \& Antonopoulos, 2015; Numerato, 2015) and doping occur (e.g., Bell, Ten Have, \& Lauchs, 2016; Engelberg, Moston, \& Skinner, 2015). Given that the factors contributing to corruption are multifarious (Caiden, Dwivedi, \& Jabbra, 2001), we would be wrong to assume that individual explanations for match fixing and doping are solely responsible for corrupt practices in college sport; or that deviance or financial motivations are the central causes of all NCAA corruption (Cullen, Latessa, \& Jonson, 2012). For example, the aforesaid reasons do not explain why a faculty member or academic staff person would commit academic fraud. In the case of University of North Carolina at Chapel Hill academic fraud, a department staff member was motivated to assist student-athletes to pass courses because of empathy and wanting to help them succeed (Wainstein, Jay, \& Kukowski, 2014). To accurately depict the range of factors that contribute to NCAA sport actors engaging in corrupt behaviours warrants an interdisciplinary investigation to help chart its complexity.

The NCAA provides a rich setting for generating an integrated theoretical framework of micro-level explanations for intercollegiate sport actors' engagement in corruption (Humphreys, 2012). First, the NCAA setting affords a local context to uncover how group interactions in organizations, peer groups, and sport programs affect people's propensity to abuse the relationships of trust and violate rules. Second, the NCAA context permits cross-case analysis that is particularly useful in understanding the process of corruption (Langseth, 2016), that is, individuals' courses of thoughts and actions leading to corrupt behaviors. Third, NCAA cases allow for the examination of individual explanations of corruption across numerous sports (e.g., baseball, women's rowing, volleyball, football, men's and women's basketball, men's and women's golf), ranges in intensity (i.e., gravity and quantity), and hierarchies (i.e. acts and levels of organizational involvement) thus allowing cross comparisons of explanations of severity and by different sports. A conglomerate of 
social, economic, sociological, and psychological factors can be used to explain why sport actors engage in intercollegiate corruption and thus the need for contextual-related research that can ultimately yield an interdisciplinary framework (Collins, Uhlenbruck, \& Rodriguez, 2009; Gorsira, Denkers, \& Huisman, 2016). Last, intercollegiate athletics offers a context where the forms and their types of corruption are unique to the setting (e.g., academic fraud, impermissible benefits, knowingly influencing others to furnish false information). The NCAA has a distinct self-monitoring compliance system where the majority of forms and types of corruption are not illegal. The findings therefore afford the opportunity for future comparative analysis of factors contributing to other sport industry forms and types of corruption (e.g., international betting match fixing, host bribery, tanking, salary cap abuses).

This study seeks to accomplish this aim by examining individual-level explanations of corruption in the context of intercollegiate athletics. The study was guided by two research questions: (1) who are the actors engaging in NCAA corruption; and (2) what factors influence athletic department stakeholders in deciding to engage in NCAA corruption. By conducting a multi-case analysis of individual-level explanations in this NCAA context, the contribution of this work is fourfold. First, it generates an interdisciplinary framework that includes micro-level factors that explain individuals' decisions to commit corruption within intercollegiate athletics. Second, empirical understandings are gained as to why a range of athletic department actors engage in corruption. Third, in practice, management strategies are ascertained that can address personal and/or micro-level corruption. Fourth, individual-level norms that can lead to corruption and, therefore, inform reform efforts become better understood.

\section{Defining sport corruption}

Across the literature the definition of corruption is a contested concept. To date, corruption scholars continue to wrestle with defining and conceptualizing corruption (Collins et al., 2009; Masters, 2015) and have yet to accept a universal definition of corruption (Langseth, 2016). In the management literature, a broad, rational-choice definition of corruption is generally used, that is, the abuse of power for personal, subunit, and/or organizational gain (Anand, Ashford, \& Joshi, 2004; Zaloznaya, 2014; Zyglidopoulos, Fleming, \& Rothenberg, 2009). A wide array of unethical and criminal acts fall under this definition including, fraud, bribery, conflicts of interest, embezzlement, and nepotism. Whilst the rational-choice approach to defining corruption is well accepted in the broader literature and, to some degree, in the sport literature, it narrowly assumes that all corruption is "purely instrumental and premeditated" that is, based on maximizing personal and/or group benefits (Zaloznaya, 2014, p. 190). Zaloznaya (2014) argues that such an assumption that all explanations for carrying out corruption are fixed and thus do not warrant further investigation. I am arguing that Zaloznaya's assumption is incorrect because it insinuates that individual accounts of corruption should be understood solely on explaining motivations for personal gain rather than exploring other factors that individuals' might take into account in deciding to engage in corrupt acts. Rationalizations and motivations for 
sport corruption are multiple and influenced by a range of informal norms (e.g., loyalty, secrecy) and social contexts (e.g., sport, educational institutions). Thus, a definition of sport corruption should incorporate these interactional influences.

Sport management scholars have also yet to agree on a single, common definition of corruption that is applicable across contexts within the sport industry (Bricknell, 2015; Masters, 2015). Maennig (2005, 2008) provided one of the first demarcations of sport corruption by distinguishing competition (e.g., athlete behaviors, intentionally not trying to win) and non-competition corruption (e.g., sporting officials' behaviors who neglect their expected positional tasks). Gorse and Chadwick (2010) suggested an alternative definition, "involving any illegal, immoral or unethical activity that attempts to deliberately distort the result of a sporting contest for the personal material gain of one or more parties involved in that activity" (p. 42). However, both of these definitions fail to capture the scope of corrupt behaviors evident in the NCAA. Maennig's (2005) non-competition definition has some applicability to the NCAA context (officials who neglect positional tasks) but does not encompass the range of malfeasance prohibited by the NCAA rules. In addition, his competition definition is focused on match manipulation, which is too narrow for an intercollegiate setting. Gorse and Chadwick's (2010) conception is limited to match manipulation of sporting contests, which has limited applicability to the range of standards of behavior required by NCAA regulations.

The delivery of NCAA athletics programs operate within higher education. The required standard of conduct expected of organizational stakeholders is based on "the integrity of the NCAA Collegiate Model" as stated in the association's constitution and bylaws (NCAA, 2016, para. 1). NCAA regulations apply to a range of stakeholders (e.g., athletes, coaching staff, athletic administrators, support staff, institutional administrators and staff, faculty, athletic representatives) and involve a wide-reaching standard of behaviors (e.g., institutional control, permissible offers and inducements, sportsmanship and ethical conduct, and permissible awards, benefits and expenses) in the administration of athletic departments, sports programs, sports rules and competitions, and academic programs. A severe breach of conduct (i.e., corrupt act) as defined in the association's constitution and bylaws is considered a major violation and in the revised structure a "level 1 violation" (National Collegiate Athletic Association, 2016, para. 1). It is noteworthy that certain standards and the different levels of infractions are specific to an intercollegiate setting (e.g., academic eligibility, institutional control, amateurism) that create complexities in seeking an understanding of individual accounts of rule breaking in a higher education setting. Sport corruption in this study is defined as "acts of appropriation and exchange that undermine, subvert, or repudiate the collectively agreed-upon organizational missions or institutional roles for non-collective ends and purposes" (Zaloznaya, 2014, p. 194). Based on the NCAA manual and existing literature (e.g., Kihl, Ndiaye, \& Fink, 2018), these acts include fraud, defined as "involving some form of trickery, swindle or deceit" that can involve "a manipulation or distortion of information, facts and expertise" (Andvig \& Fjeldstad, 2001, p. 9). 
Examples of types of fraud in the NCAA include academic misconduct, impermissible financial aid, and impermissible recruiting, tryouts and workouts. Bribery refers to either actively offering a bribe or passively receiving a bribe that includes such behaviors as offering or receiving improper gifts, peddling privileges, bribery to supporting unfair competition, and securing confidential information (Langseth, 2016, pp. 25-26). Unethical conduct is defined as "a set of guiding principles with which each person follows the letter and spirit of the rules" (NCAA, 2018, para. 5). Example prohibited behaviors are impeding an investigation, failing to cooperate during an investigation, or refusing to provide all relevant or requested information during an investigation.

Zaloznaya's (2014) definition goes beyond the traditional rational choice definition of corruption (corruption as abuse of entrusted power for private gain) as it is founded in social psychology traditions acknowledging that corruption is context determinant and people's social interactions with rules influence how and why individuals decide to engage in corruption. Such a definition is the foundation for creating an interdisciplinary framework that reflects how NCAA actors make sense of the rules system and the context influencing factors that guide their decision making. This definition also demarcates corrupt behaviors from other forms of organizational wrongdoing or misconduct (e.g., bullying, sexual harassment) by emphasizing misappropriation of the association's mission and guiding principles.

\section{Literature Review}

\section{Moral disengagement}

Moral disengagement theory explains how individuals deactivate their internal self-regulatory capabilities (e.g., guilt, shame, and self-condemnation) that typically stop them from violating their moral standards. Moral engagement mechanisms disable the self-regulatory processes and as a result, individuals participate in wrongdoing without feeling personal distress (Bandura, 1999, 2002; Bandura, Caprara, \& Zsolnai, 2000). Moore, Detert, Trevino, Baker, and Mayer (2011) argued the moral disengagement process plays an important role in explaining how individuals are able to "engage in corruption without apparent cognitive distress" (p. 4). Athletes have used several moral disengagement mechanisms to justify doping including advantageous comparison (comparing detrimental acts with more harmful ones, and making appear less worse), minimizing consequences, and diffusing responsibility (Bell et al., 2016; Engelberg et al., 2015; Kirby, Moran, \& Guerin, 2011). Athletes who doped believed their behavior was not as bad in comparison to athletes committing serious crimes such as sexual assault or murder (e.g., Engelberg et al., 2015). Athletes also justified doping by arguing that minimal health side effects were found in using drugs and the immense pressure teammates placed on them to conform (Bell et al., 2016; Engelberg et al., 2015; Kirby et al., 2011). Furthermore, Pappa and Kenney (2013) reported doping was standard practice in competitive sport, specifically track and field. Athletes perceived that doping was a common secret that went unquestioned, was rationalized as normal, routine, everyone is doing it, and 
a necessary activity if one wanted to compete at a higher level (Kirby et al., 2011; Lentillon-Kaestner \& Carstairs, 2010; Pappa \& Kenney, 2013). Given the "social nature of moral disengagement", how intercollegiate actors justify corruption and the influencing factors "may be quite specific to particular environments" (Boardley \& Kavussanu, 2011, p. 104). Moral disengagement has yet to be examined in understanding individual accounts of corruption in intercollegiate athletics. Intercollegiate actors may or may not justify corrupt acts based on advantageous comparison, minimizing consequences, and diffusing responsibility.

\section{Rational choice}

Rational choice theory contends that individuals engage in corruption through calculating the cost versus the benefits and thus make a decision when they believe the benefits outweigh the costs (Lastra, Bell, \& Bond, in press; Numerato, 2015; Palmer, 2012). Corruption is, therefore, deemed as an instrumental premeditated action that is motivated by maximizing personal benefits at the expense of an organization, or public or private goods (Jancsics, 2014). Rational choice explanations of individuals engaging in sport corruption specifically match-fixing, doping, and NCAA corruption are motivated by goal orientations (achievement/performance and winning) and financial gains.

In the context of match-fixing, gambling-motivated fixing seeks to achieve "economic gain indirectly from manipulating field activities for a complete or partial result through betting activity" and non-gambling motivated fixes aim to "achieve a sporting advantage directly from its result" (KEA, 2012, p. 10). Players, coaches, and officials who fix matches for financial gain primarily due to low salaries or delayed salaries (Carpenter, 2012; Hill, 2015), duress (Carpenter, 2012; Forrest, McHale, \& McAuley, 2008; Hill, 2010; Spapens \& Olfers, 2015), career advancement (Boeri \& Severgnini, 2011), and older players nearing retirement (Hill, 2015). Individuals (players/officials) spot fix (a specific aspect of a game, unrelated to the final result, is fixed for financial gain) because they experience less guilt and believe there is less risk associated with manipulating aspects of a game, therefore, such individuals are more prone to agreeing to spot fix (Carpenter, 2012). Furthermore, in assessing the risks and benefits, research has shown that individuals in certain countries (i.e., Greece and Lebanon) generally believe accountability for match-fixing is nonexistent because they feel politicians protect corrupt actors (Manoli \& Antopoulos, 2014; Nassif, 2014).

Goal orientation explanations suggest that in the context of doping, athletes dope to achieve their high standard goals of performance and winning (Engelberg et al., 2015; Ehrnborg \& Rosén, 2009; Kirby et al., 2011; Pappa \& Kennedy, 2013); which is arguably a narrow rationale for explaining doping. Over time, athlete motivations to dope have evolved where critical incidents lead to more pragmatic factors such as injury recovery, time off from sport, a series of poor performances, and to sustain participation (Engelberg et al., 2015; Kirby et al., 2011). In comparison, Feustel and Rodenberg (2015) found match-fixing was motivated within the promotion/relegation model where asymmetric incentives influence teams seeking promotion (or 
avoiding relegation), will approach opponents with little incentive to win (or need to avoid relegation) to fix a match.

Studies investigating factors contributing to corruption within intercollegiate athletics is minimal and has mostly used meso and macro-economic rational models and/or environment forces (Clark \& Batista, 2009) influencing corruption. Fizel and Brown's (2014) economics-based model of the multi-institutional aspects of a NCAA major football program found that university characteristics (i.e., Win-Loss record and stadium capacity), leadership (coaches tenure), conference rivals, public/private university status, and different enforcement regimes were all significant influencing factors that lead to corruption. Balsdon, Fong, \& Thayer (2007) found evidence of "tanking" of games by college basketball teams in conference tournaments to place an additional team in the national tournament, to generate revenue. Scholars have also examined environmental forces that lead to NCAA violations. Clark and Batista (2009) showed that sports programs at the highest competition level-BCS-affiliated conferences-commit more recruiting infractions than in the lower competition non-BCS conferences. Whereas, Davis (1999) found major violations occurred equally in both BCS and non-BCS affiliated programs and violations were committed by both revenue and non-revenue sports programs. Rational choice approaches to examining NCAA corruption focuses on macro-level analysis that do not address why individuals engage in corrupt practices in this context or if similar rational choice factors in deciding to dope or engage in match fixing would be observed in NCAA malfeasance.

\section{Relational model: Social networks}

Relational approaches concentrate on networks of social relationships (Jancsics, 2014) in understanding corruption. Individuals form sustainable networks with the aim of profiting from the relationship through informal exchanges (Blau, 1964). Two types of corrupt network models exist: horizontal networks involving trust-based and intimate relationships; and vertical networks comprised of asymmetrical actors that use power to influence exchanges. Relationships range from weak to strong. The "strength" of an interpersonal tie is based on the frequency of interactions, emotional intensity, and intimacy of the relationship (Brass, Butterfield \& Skaggs, 1998; Granovetter, 1973). Research shows that social networks are factors that contribute to doping (Bell et al., 2016; Pappa \& Kenney, 2013). An athlete's social network contains referent groups that place considerable pressure on athletes to dope (Bell et al., 2016; Engelberg et al., 2015; Kirby et al., 2011; Paoli \& Donati, 2014). An athlete's social network can be comprised of athletes, coaches, doctors, and/or administrators, any of whom may rationalize and normalize doping, and/or may apply pressure to athletes to conform, perform and/or win, or maintain a code of silence. Bell et al. (2016) reported that "[The] Lance Armstrong-UPS Team network inflicted harm through methods such as bribery, bullying, and threats of physical assault" (p. 4) to ensure athletes conformed. In contrast, Kirby et al. (2011) found athletes felt pressured to dope to gain their teammates' trust. 
Match-fixing can also be understood in the context of relational models or social networks (Hill, 2013; Lee, 2017). Individuals involved in match-fixing activities typically occur through networks that are "fluid and dynamic social systems that consist of patterns of relationships among people and/or actors" (Manoli \& Antonopoulos, 2015 , p. 207). Numerato (2015) argued social networks operate in a climate of secrecy where match-fixing is normalized and reinforced by a compromising complicity of social actors (i.e., players, teams, referees, sport association officials or journalists). Match-fixing in Taiwanese professional baseball was attributed to Confucian ideology where the values and symbols of Confucianism have a profound influence on an individual's place in the hierarchy of social and familial relationships (Lee, 2017). In this system, Lee (2017) argues that athletes are required to display strict obedience, collective harmony, and loyalty to their coaches and thus do not question directions to fix matches Hill (2010) argued social mechanisms of strong illegal gambling networks, a high degree of player exploitation, and an expectation of complicity by corrupted officials lead to high levels of corruption.

Match-fixing social networks can range from highly organized and structured global criminal betting syndicates such as found in certain gambling fixes to less structured and dyadic in nature observed in locally arranged fixes (Hill, 2013). Global criminal networks organize around betting syndicates in different national contexts where they can influence athletes, coaches, referees, and /or administrators to pursue their illegal interests (e.g. Hill, 2010; 2013, 2015). Dyadic and/or less organized social networks generally occur as a result of either threats or reward by club administrators (Manoli \& Antopoulos, 2015), coaches (Lee, 2017), or gamblers (Hill, 2009a, 2009b, 2010). The motivations behind the rewards or threats are mostly financially related where they approach individuals who they believe can be bribed and/or intimidated (Hill, 2009a, 2009b, 2010; Manoli \& Antopoulos, 2014).

In review, previous research suggests a range of social mechanisms influence match-fixing as shown by various case studies of different countries (e.g., Hill, 2010; Lee, 2017; Numerato, 2015; Manoli \& Antopoulos, 2015). Sports match-fixing involves the cooperation between different actors that range from a simple group to a systematic network. Unclear in the sport corruption literature is if different types of corruption (e.g., fraud, bribery) carried out by individuals in amateur sport (e.g., intercollegiate athletics) involves such social networks to commit malfeasance or an understanding of the nature of the networks.

\section{Criminology approach}

To date, Cullen et al.'s (2012) research is one of the few studies that have performed a micro-level empirical analysis of why intercollegiate athletes' (football and men's basketball) violated NCAA rules. Framed from criminology theory, they found namely, differential association, propensity, and social control significantly predicted rules violations. In particular, both football and basketball athletes were more than likely to engage in malfeasance when they associated with friends who violated rules, were highly recruited athletes and/or transfer athletes, and athletes that identified as religious fundamentalists. Framing individual-level explanations NCAA violations 
from a criminology perspective is based on the assumption that NCAA violations are crimes. Furthermore, only sampling athletes fails to acknowledge how social interactions influenced corrupt behaviors. Ridpath, Gurney, and Snyder's (2015) examination of academic fraud in NCAA Division I Men's basketball and football built on Cullen et al. (2012) and found a variety of internal (athletic administrators, staff, coaches, student tutors, graduate Assistants) and external (faculty, athletic boosters, university administrators) athletic department actors were involved. Thus, showing some evidence of the need to understand which sport actors are involved in specific forms and types of NCAA corruption. Individual-level explanations of sport corruption are understudied, especially in NCAA context, where a wide array of sports, actors, and forms of corruption exists. Regrettably, we lack an interdisciplinary framework that incorporates micro-level factors theorized by different disciplines that could explain factors that contribute to corruption within the context of intercollegiate athletics. Furthermore, the field is absent of such a framework that is based on empirical research, thus further demonstrating the importance of this research.

\section{Methods}

A multiple-case sampling technique (Miles, Huberman, \& Saldana, 2014) was used to address the study's twofold aim of examining individual-level explanations for engaging in corruption in NCAA Division I athletics and generating a subsequent interdisciplinary framework. Multi-case sampling is a suitable approach to gain an in-depth understanding of a phenomenon (Miles et al., 2014; Stake, 1995) and for generating theory (Eisenhardt, 1989). Examining a range of cases for similarities and differences helps gain new knowledge and/or strengthens existing theory (Miles et al., 2014); in this context, seeking insights in what ways and reasons NCAA athletic department stakeholders commit corruption. Multiple-case sampling also strengthens the confidence and overall trustworthiness of the findings through investigating how, where, and why phenomena occur across cases (e.g., Miles et al., 2014, Strike, 1994).

A purposive sampling technique was first employed where instrumental case selection was based on addressing the study's aim and included the following criteria: a) a Division I member category; b) the institution had violated one or more major infractions legislation (as defined by the NCAA and corresponded with the study's operational definition of NCAA corruption); c) the availability of gaining access to detailed infractions reports; and d) cases that occurred within a 10 year time period from 2005-2015. The decade time period was selected to gain a contemporary cross analysis of individual-level explanations within NCAA corrupt cases. The NCAA does not maintain public records of secondary infractions. Thus, secondary infractions cases did not meet the inclusion criteria and where not included in the study. Based on the purposive sampling criteria, data were collected from the NCAA's Legislative Services Database (LSDBi) website (NCAA, 2016). The LSDBi contains reports on each case of major infractions. Case reports document the actors who were involved, the circumstances that lead to the corruption, the types of corruption 
that occurred, the extent of the corruption, investigative evidence that supported the reasons for engaging in corruption, and sanctions.

During the decade time span, a total of 126 cases of corruption were documented in the LSDBi (NCAA, 2016). From the 126 instrumental cases, a random sample (through a random sample generator) of 20 case reports were selected for analysis. A multiple case study design reflects replication logic similar to using multiple experiments when seeking to replicate results (Yin, 2014). Rather than adopting a sampling logic that seeks a representative sample, Yin (2014) argues that multi-cases aims for theoretical replication where selected cases in the aggregate can support the initial research proposition. Thus, in relation to this case, replication logic was used for selecting the 20 cases to propose an interdisciplinary framework of micro-level accounts of sport corruption in intercollegiate athletics as well as to enhance credibility of the study (Marshall \& Rossman, 2014; Maxwell, 2013; Patton, 2002). Random purposeful sampling is commonly used to promote confidence in accurately recording the phenomena under study (Lincoln \& Guba, 1985) and to ensure "characteristics of similarity, dissimilarity, redundancy and variety, are sought in order to gain greater knowledge of a wider sample" (Stake 1994, p. 240). Miles et al. (2014) also assert that the number of cases included in a multiple-case study is based on a conceptual argument, that is, "the number of cases that provide confidence in the findings, the richness and complexity of the cases, and the feasibility of collecting and managing the amount of data" (p. 34). Thus, there are no hard rules on sample size but guidelines to use based on the research purpose and context. Patton (2002), in particular, argues that the aim of a random sample is "credibility not representativeness. A small, purposeful random sample aims to reduce suspicion about why certain cases were selected for study" (p. 241). He further argued "the credibility of systematic and randomly selected case examples is considerably greater than the personal, ad hoc selection of cases ..." (p. 241). Since the reports were secondary data, it was also deemed appropriate to randomly select 20 cases in the study (Lincoln \& Guba, 1985; Patton, 2002). The case reports averaged 22.45 single pages in length, ranged from 12-58 pages, and totaled 449 pages of raw data. Bell et al. (2017) maintain that case reports are an acceptable data collection method for studying sport corruption because of the challenges associated with collecting field data and gaining access to participants who actually engaged in malfeasant behavior.

Data analysis was guided by Miles et al.'s (2014) qualitative cross-case data analysis process involving first cycle (open coding) and second cycle coding (pattern coding) that was carried out by two researchers. First, the 20 major infractions reports were downloaded, read and re-read for familiarity. Codes were then deductively created from the corruption literature (e.g., Cullen et al., 2012; Engelberg et al., 2015; Frost \& Tischer, 2014; Hill, 2010; Lee, 2017; Numerato, 2015; Peurala, 2013). Third, using the qualitative software ATLAS ti. (Scientific Software Development, 2016) the reports were deductively and inductively openly coded. Open coding is a process of tagging data and organizing it into conceptual categories that represented who, what, how, and why individuals committed corruption. An example deductive code included motivation - financial - meant an individual participated in corrup- 
tion for financial reasons. Inductive open coding was also carried out where in vivo codes were created from the reports and respectively tagged. An example in vivo code was rationalization - neutralizing - humanitarian - represented an individual justifying committing a violation because he/she wanted to help the welfare of a student-athlete. Fourth, pattern coding was then performed to identify common themes in terms of understanding how and what factors influenced individuals in their decisions to violate the rules (Miles et al., 2004). Within these two coding processes, cross-case analysis was performed to compare and contrast similar and different characteristics among the cases in terms of who was involved in the rule violations, the events that led up to the violations, and what factors were attributed to their decisions to commit rule violations. Conceptual saturation was achieved as each pattern and theme was fully developed (Corbin \& Strauss, 2015). The two researchers who carried out this open and pattern coding process discussed and sought agreement on code development, tagging of the data, and pattern identification. Last, content analysis summary tables were created for each case, followed by the generation of a meta-analysis matrix where all the data was condensed into one table organized by key concepts related to addressing the research questions.

\section{Findings and Discussion}

The findings are organized around two main themes. First, a summary of the multicase demographic information. Second, individual-level explanations of athletic department actors engaging in corruption. The findings are discussed in relation to relevant corruption literature, where the contribution of this work is accentuated.

Multi-case demographics

Table 1 shows a variety of athletic department stakeholders (e.g., athletes, recruited athletes, academic counselors, compliance staff, athletic representatives, and coaches' relatives) were involved in corruption, however, the majority of actors were head coaches or assistant coaches. The sports of football $(n=10)$ and men's basketball $(n=9)$ reported the most violations (see table 2$)$ yet men's and women's non-revenue/Olympic sports (i.e., men's track and field, men's and women's cross country, men's and women's tennis, volleyball, women's basketball, women's swimming and diving) also reported violations. One case reported corruption in eight sports and one reported violations across all sports. Fraud was the most frequent form of corrupt act committed by athletic department stakeholders with 30 violation types (e.g., academic, impermissible benefits, impermissible financial aid, impermissible contacts, and ineligible participants) reported, followed by 13 unethical conduct violations, and five bribery violations. Table 2, documents the forms and example types of corrupt activities that occurred in each sport. Within each case analyzed, more than one violation was reported.

Critics of intercollegiate athletics have argued that corruption is rife across revenue sports because of rational choice motivations of winning and financial gains (e.g., Fizel \& Brown, 2014), however, the demographic data showed that corruption was prevalent across both revenue and non-revenue/Olympic sports. The motiva- 
Table 1. Athletic Department Actors Involved in Major Violation

\begin{tabular}{|ll|}
\hline Actors & Violations (n) \\
\hline Academic Advisor & 2 \\
AD & 2 \\
Family of Athletic Staff & 2 \\
Assistant Coaches & 16 \\
Athletic Representative & 2 \\
Compliance Assistant & 1 \\
Compliance Director & 1 \\
Football Support Staff* & 6 \\
Head Coach & 24 \\
Institution & 4 \\
Academics in Institution & 2 \\
Promotor & 1 \\
Student Workers & 1 \\
\hline
\end{tabular}

*External relations, operations, player personnel, program, strength \& conditioning, and graduate assistant each were involved in a major violation case.

tions and pressures to win in relation to job security, salary increases, status/prestige, were displayed across all sports. Furthermore, the findings demonstrated the predominance of fraud and unethical conduct violations were committed by a range of athletic department actors. Individual level explanations of NCAA violations have focused solely on athlete motivations (Cullen et al., 2012), thus these findings contribute to the literature by demonstrating the scope of individuals involved in NCAA violations and the form of corruption committed.

\section{Individual-level explanations of corruption}

The findings are organized into three main interrelated themes of individual explanations for engaging in NCAA corruption: 1) psychological motivations (social relationship and self-interest, and personal norms), 2) professional (abuse of power and failure of responsibilities), and 3) justifications (rationalizing strategies). The respective influencing factors are explained in more detail next. 
Table 2. Sports, Number of Major Violations, Form, and Types

\begin{tabular}{|c|c|c|c|}
\hline Sports & $\begin{array}{l}\text { Violations } \\
\text { (n) }\end{array}$ & Form & Types (examples) \\
\hline \multirow[t]{2}{*}{ All sports } & 1 & Fraud $(\mathrm{n}=1)$ & $\begin{array}{l}\text { Failure to meet eligibility re- } \\
\text { quirements }(\mathrm{n}=)\end{array}$ \\
\hline & & & $\begin{array}{l}\text { Participation by ineligible SA } \\
(\mathrm{n}=1)\end{array}$ \\
\hline 8 sports & 1 & Fraud $(\mathrm{n}=1)$ & $\begin{array}{l}\text { Impermissible texts and phone } \\
\text { calls }(n=1)\end{array}$ \\
\hline \multirow[t]{4}{*}{ Football } & 10 & Fraud $(n=10)$ & Academic $(n=2)^{*}$ \\
\hline & & & $\begin{array}{l}\text { Impermissible extra benefits } \\
(n=5)\end{array}$ \\
\hline & & $\begin{array}{l}\text { Unethical con- } \\
\text { duct }(\mathrm{n}=2)\end{array}$ & $\begin{array}{l}\text { Failed to meet standards of hon- } \\
\text { esty \& sportsmanship }(n=2)^{*}\end{array}$ \\
\hline & & & $\begin{array}{l}\text { Knowingly instructing to furnish } \\
\text { false/misleading information } \\
(\mathrm{n}=1)\end{array}$ \\
\hline \multirow[t]{2}{*}{$\begin{array}{l}\text { Men's \& women's } \\
\text { cross country }\end{array}$} & 1 & Fraud $(\mathrm{n}=1)$ & $\begin{array}{l}\text { Impermissible recruiting benefits } \\
(\mathrm{n}=1)^{*}\end{array}$ \\
\hline & & & $\begin{array}{l}\text { Impermissible recruiting contacts } \\
(\mathrm{n}=1)\end{array}$ \\
\hline $\begin{array}{l}\text { Men's \& women's } \\
\text { swimming \& diving }\end{array}$ & 1 & Fraud $(n=1)$ & $\begin{array}{l}\text { Impermissible extra benefits } \\
(n=1)\end{array}$ \\
\hline \multirow[t]{6}{*}{ Men's basketball } & 9 & Fraud $(\mathrm{n}=8)$ & Impermissible tryouts $(\mathrm{n}=4)^{*}$ \\
\hline & & & $\begin{array}{l}\text { Failure to promote compliance } \\
(\mathrm{n}=4)\end{array}$ \\
\hline & & & $\begin{array}{l}\text { Impermissible recruiting induce- } \\
\text { ments }(n=3)\end{array}$ \\
\hline & & & Academic $(n=2)$ \\
\hline & & Bribery (n-2) & $\begin{array}{l}\text { Impermissible recruiting induce- } \\
\text { ments }(n=2)\end{array}$ \\
\hline & & $\begin{array}{l}\text { Unethical con- } \\
\text { duct }(n=5)\end{array}$ & $\begin{array}{l}\text { Failed to meet standards of hon- } \\
\text { esty \& sportsmanship }(n=3)^{*}\end{array}$ \\
\hline
\end{tabular}


Table 2. Sports, Number of Major Violations, Form, and Types (cont.)

\begin{tabular}{|c|c|c|c|}
\hline \multirow[t]{5}{*}{ Men's tennis } & \multirow[t]{5}{*}{2} & Fraud $(\mathrm{n}=2)$ & $\begin{array}{l}\text { Eligibility legislation violations } \\
(\mathrm{n}=1)^{*} \\
\text { Academic fraud }(\mathrm{n}=1)\end{array}$ \\
\hline & & Bribery $(\mathrm{n}=1)$ & $\begin{array}{l}\text { Impermissible extra benefits } \\
(\mathrm{n}=1)\end{array}$ \\
\hline & & \multirow[t]{3}{*}{$\begin{array}{l}\text { Unethical con- } \\
\text { duct }(n=1)\end{array}$} & $\begin{array}{l}\text { Knowingly arranging impermis- } \\
\text { sible benefits \& academic fraud } \\
(\mathrm{n}=1)^{*}\end{array}$ \\
\hline & & & $\begin{array}{l}\text { Knowingly furnishing mislead- } \\
\text { ing information }(n=1)\end{array}$ \\
\hline & & & $\begin{array}{l}\text { Failed meet standards of honesty } \\
\& \text { sportsmanship }(n=1)\end{array}$ \\
\hline \multirow[t]{4}{*}{ Men's track \& field } & \multirow[t]{4}{*}{2} & \multirow[t]{2}{*}{ Fraud $(n=2)$} & $\begin{array}{l}\text { Impermissible recruiting benefits } \\
(\mathrm{n}=1)^{*}\end{array}$ \\
\hline & & & $\begin{array}{l}\text { Impermissible recruiting contacts } \\
(\mathrm{n}=1)\end{array}$ \\
\hline & & \multirow[t]{2}{*}{$\begin{array}{l}\text { Unethical con- } \\
\text { duct }(n=2)\end{array}$} & $\begin{array}{l}\text { Knowingly involved in recruiting } \\
\text { violations }(\mathrm{n}=1)^{*}\end{array}$ \\
\hline & & & $\begin{array}{l}\text { Failed meet standards of honesty } \\
\& \text { sportsmanship }(n=2)\end{array}$ \\
\hline \multirow[t]{2}{*}{ Volleyball } & \multirow[t]{2}{*}{2} & \multirow[t]{2}{*}{ Fraud $(n=2)$} & $\begin{array}{l}\text { Improper use of correspondence } \\
\text { courses for academic progress } \\
(\mathrm{n}=1)\end{array}$ \\
\hline & & & Ineligible competition $(\mathrm{n}=1)$ \\
\hline \multirow[t]{3}{*}{ Women's basketball } & \multirow[t]{3}{*}{4} & \multirow[t]{2}{*}{ Fraud $(n=4)$} & Impermissible extra benefits $(n=2)$ \\
\hline & & & $\begin{array}{l}\text { Impermissible tryouts \& out of } \\
\text { season practice activities }(n=1)\end{array}$ \\
\hline & & Bribery $(n=1)$ & Impermissible extra benefits $(n=1)$ \\
\hline \multirow[t]{3}{*}{ Women's tennis } & \multirow[t]{3}{*}{1} & Fraud $(n=1)$ & $\begin{array}{l}\text { Impermissible recruiting } \\
\text { benefits }(n=1)^{*} \text { impermissible } \\
\text { recruiting contacts }(n=1)\end{array}$ \\
\hline & & \multirow[t]{2}{*}{$\begin{array}{l}\text { Unethical } \\
\text { conduct } \\
(\mathrm{n}=1)\end{array}$} & $\begin{array}{l}\text { Knowingly involved in re- } \\
\text { cruiting violations }(n=1)^{*}\end{array}$ \\
\hline & & & $\begin{array}{l}\text { Failed meet standards of hon- } \\
\text { esty \& sportsmanship }(n=1)\end{array}$ \\
\hline
\end{tabular}

*Several types of corruption were reported with one instance but not included in the table 


\section{Psychological: Motivations}

Individual motives (i.e., reasons) for engaging in NCAA corruption included social relationships and self-interest (winning, competitive advantage, eligibility, and material gain).

Social relationships consisted of horizontal networks (informal personal social networks/friendships) and vertical networks (social relationships that involve asymmetrical power relationships). The NCAA relationships were generally positive (i.e., actors were cooperative and/supportive in the relationship) and entered voluntarily, which was unlike many of the bribery match-fixing cases where relationships were adversarial as crime syndicates engaged in intimidation in relationship development and maintenance. Similar to some match-fixing networks (e.g., Hill, 2009b; Manoli \& Antonopoulos, 2014; Numerato, 2015), the relationships in this study were mostly simple and unsophisticated. Relationships were deemed simple and unsophisticated because: a) the actors were linked by one type of relationship (e.g., professionalhead coach and a high school coach, a spousal relationship, or an assistant coach and athletic department representatives) versus multiplex relationships (linked by more than one type of relations (e.g., friend, business associate, relative). The simple relationships were in contrast to the corrupt networks reported by Bell et al (2016) and Hill (2013) who found criminal associations (i.e., dark networks) and institutionalized network systems comprised of specialists and team members to sustain corruption. In certain cases the actors were linked through simultaneously by a personal/ intimate relationship and a professional relationship; and b) the network of relationships were relatively small in number (e.g., two-four members). The family and/ or professional links were similar to the Confucian society family system reported by Lee (2017). Lee (2017) found social norms influenced friends and family members to offer indirect and direct support to "one's own people" (p. 16). In this study, relationships among spouses of coaches of non-revenue sports or coaches and/or athletes' ties with church and cultural community members' assumedly were a factor for the development of simple corrupt networks as they sought to help "family." Recruiting (including recruiting related academic fraud) corrupt behaviors involved small network relationships that were secretive and/or lacked surveillance. Opportunities arose for corrupt practices because small network members failed to question rule violating behaviors and more than likely their behaviors occurred unobserved. Spouses of coaches of non-revenue sports, and church and cultural community members' activities were not under surveillance and thus provided an opportunity for corrupt behavior. Thus, the NCAA's compliance system seems ineffective in controlling these types of family networks corrupt behaviors.

Social relationship strength varied between actors, however, the horizontal nature of the relationship (i.e., personal and professional) was a motivational foundation for committing several different forms of fraud. The strength of a relationship is based on a combination of the extent, the emotional intensity, intimacy, and reciprocity of a connection (Brass et al., 1998; Granovetter, 1973). In this study, the relationships were generally strong because the ties were direct, involved a person with the authority to influence, and the individuals trusted one another. Frequency of in- 
teraction enhances trust and has a positive affect that creates opportunities to engage in corruption and offers a payoff (Granovetter, 1973). For example, assistant coaches used their preexisting professional relationships or developed relationships with high school and club coaches to carryout recruiting fraud (Cases \#15 and 16). While a staff person involved in a personal relationship with a student-athlete was motivated to commit fraud for material- economic gain (Case \#2). Other horizontal networks between either staff, assistant coaches, and athletic representatives and athletes were motivated to commit fraud (impermissible benefits) to help athletes for humanitarian justifications (e.g., finding employment, paying for tuition, securing housing, travel, government documents, assisting in travel to return home for a family emergency (i.e., childbirth or sick parent)) (e.g., Cases \# 4, 9, 10). The following representative quotations show this relation and the range of humanitarian justification themes:

The former assistant coach characterized his actions on those two occasions as humanitarian because prospect 1 (student-athlete) had no other transportation available. (Case \# 15)

My options, I felt were not the best, but of all the options certainly, I'd rather be guilty of an extra benefit violation than have a kid being sent home in a box from getting shot at the border. (Case \# 9)

The former head coach described his motive as humanitarian, helping the family of a prospect in war-torn Serbia. (Case \#4)

Athletic department representatives who had strong relationships with international student-athletes were also prone to provide impermissible financial support. Despite being advised not to financially assist athletes, representatives had paid athlete's tuition, accommodations, use of credit cards, cash payments, and payment of bills (Cases \# 4, 10). For example, case \#10 documented a representative learning that an international student-athlete:

"had returned from her native country, was enrolled in school, but did not have sufficient funds to pay her bills due to additional course work and the necessity to pay out-of-state tuition. The representative contacted student-athlete 1 directly and offered to pay her tuition, an offer the student-athlete accepted."

The athlete representative rationalized the behavior by arguing that the assistance was necessary for successful degree completion because athletic scholarships did not pay out of state tuition. The recruitment of highly skilled international athletes provides an opportunity for fraud by assisting student-athletes with impermissible accommodations and financial support prior to and during their playing eligibility. Many international athletes did not have the financial means to support themselves prior to the start of an academic term. Assistant coaches often utilized their horizontal social networks with athlete representatives and their communities (e.g., church or cultural) to arrange for support, which often led to these representatives devel- 
oping strong relationships with the athletes that continued throughout the athletes' playing eligibility.

Interpersonal conflict within a horizontal personal relationship also lead to certain rule breaches in terms of retaliation or a deliberate failure to fulfill responsibilities. For example, staff/assistant coaches' previous conflict with a superior (i.e., head coach or an administrator) weakened vertical relationships between these actors, which led to subordinate staff persons failing to communicate possible and/or report violations. Brass et al. (1998) contend that "lower-level employees feel less obligated to monitor or whistle-blow on higher ups" (p. 24). In this study, however, interpersonal conflict created poor working relationships between these staff members and organizational leaders, and thus staff felt less obliged to approach them about their corrupt activities.

Individual self-interest and/or rational cost/benefit assessment played a role in explaining corrupt behavior. Similar to research in understanding match-fixing and doping (e.g., Carpenter, 2012; Engelberg et al., 2015; Hill, 2013; Pappa \& Kennedy, 2013), motivations to commit corrupt acts related to some degree of individual or a small group benefit. The form of corrupt acts was mainly fraud (e.g., academic, impermissible benefits, impermissible contacts) and bribery (e.g., incentives) and occurred in both non-revenue and revenue sports. Violations occurred across sport programs and all three subdivisions. The motivational benefits generally related to the desire to win through gaining a competitive advantage and bribery. For example, a head coach sought to gain a competitive advantage through continued bribery of a talented tennis student-athlete enticing him "with improper offers of cash, a vehicle and assistance with academic problems" (Case \#12). Similarly, several cases involved individuals motivated to maintain athlete eligibility by committing fraud including academic, impermissible participation of a talented athlete, and impermissible benefits (i.e., paying travel and accommodation expenses for recruits and their families).

\section{Psychological: Personal norms}

Personal norms generally refer to feelings of a "moral obligation to perform or refrain from certain actions" (Schwartz \& Howard, 1981, p. 191). Personal norms are activated through problem awareness (the extent to which someone is aware of the adverse consequences of not adhering to the rules) and feeling responsible for the respective consequences (Schwartz \& Howard, 1981; Steg \& Groot, 2010). Actors' moral obligation lapses influenced corrupt acts (i.e., fraud, bribery, and unethical conduct) in most cases. The corruption was intentional, planned and carried out, and in some instances, despite the advisement against the behavior and awareness the action was wrong. Reports stated, for example, "violations were premeditated, deliberate or committed after substantial planning ... persons of authority condoned, participated in or negligently disregarded the violation or related wrongful conduct" (Case \#14). Deliberate acts of engaging in corruption ranged from academic fraud to scheduling impermissible works. For instance, Case \#12 reported a former women's tennis head coach had scheduled a work out, 
activity ... and she went ahead with it even though she had received the compliance director's reminders and had been advised by the head men's tennis coach ("men's tennis coach") before the activity took place that it was impermissible.

A common theme across cases was both the influencing factors of individual motives (specifically, self-interest) and personal norms (disregard for rules). Kish-Gerphart et al (2010) maintain that those who "look out for number one" and/or manipulate others for their own personal gain generally make unethical (corrupt) choices at work (p. 18). In several cases NCAA sport actors who were motivated by self-interest also displayed a flippant disregard for upholding the rules, which was illustrated by an athletic department representative stating "she did not care if her actions violated NCAA rules!" (Case \#10). A report summary also specified, "The actions of the former head coach, particularly when considered with her other violations set forth in this report, reveal an alarming disregard for NCAA rules and student-athlete welfare" (case \#12). The findings showed that individuals motivated by self-interest also lacked problem awareness of the adverse consequences of committing corrupt acts (e.g., student-athlete welfare), the importance of integrity, and dismissed their ascribed responsibility to abide by the rules.

\section{Professional: Abuse of power}

Ashford and Anand (2003) argued leadership plays a vital role in institutionalizing corruption. Corruption was manifested by institutional leaders abusing their power to influence others to participate in corruption or using positional power to break norms. Asymmetrical dyadic relationships between powerful head coaches and athletic representatives raised the likelihood that coaches could use their status to pressure them to engage in corrupt practices (e.g., pressure to make a knowingly unauthorized donation). Individuals in positions of power (head coaches, assistant coaches, academic advisors) also ordered subordinates (assistant coaches, student-athletes, graduate students, and undergraduate student workers) to commit varies forms of fraud or they directed subordinates and/or prospective student-athletes and/or their families to lie about or conceal bribery and/or fraudulent behaviors (e.g., lie about impermissible contacts during unofficial visits, academic fraud). Assistant coaches were also given directives to "take care of things" or circumvent rules at "the direction and ultimately insistence of head coaches." Head coaches "chastised the assistants" if they did not confirm and were placed in a position to "either comply with the demands to break the rules or lose his job" (Case \#10). The abuse of power contributed to creating a code of silence (Bell et al., 2016), where subordinates were afraid to confront their superiors or report the inappropriate orders in fear of retribution.

Institutional leaders also concealed corrupt acts to avoid detection and in extreme cases relating to academic fraud head coaches, assistant coaches and/or academic advisors instructed student-athletes to lie and state they did their own coursework or a person proctored their tests when this information was false. The following quotations illustrates this theme, 
The assistant football coach repeatedly told student-athletes to lie about the academic fraud and about proctor A proctoring the exams" (Case \#1). The former assistant coach instructed former student-athlete 1 to "deny everything," including the instances of cheating and plagiarism (Case \#17).

Individuals in positions of power authorized corruption where "subordinates as a designated role occupant, were expected to execute the authorized acts, and not to second guess" (Ashford \& Anand, 2003, p. 7) them. The subordinates demonstrated a normative duty to comply with these directives despite it opposing their personal norms. Noteworthy, actors not formally associated with the organization (i.e., prospective student-athletes and their families) also displayed this normative duty.

Concealment of corruption as well as aggressive behavior toward investigators was also found during NCAA investigations. In most cases individuals in leadership positions (e.g., administrators, coaches, general counsel, and compliance officers) were advised to refrain from speaking to student-athletes prior to their interview with investigators. However, some administrators dismissed the investigators directive and compromised the interviews by sharing information with and/or instructing individuals how to respond to investigators' questions. For example, Case \#16 reported "in spite of being instructed by the NCAA investigator not to discuss the matter with anyone else, the former head men's basketball coach made another call to the father of prospect 1." Similarly case \#14 conveyed that "the institution, acting contrary to the explicit instructions of the AGA staff, had questioned student-athlete 2 on two occasions prior to his interview and had disclosed to him specific information, which was the subject of the interview." The report went to express the combative attitude of administrators during investigations.

The former general counsel was not the only person at the institution who conveyed a combative attitude toward the investigation. The NCAA agent, gambling and amateurism

Activities (AGA) investigator assigned to investigate the matter needed supervisory support at some interviews because the attitude of the institution's representatives was so confrontational.

The abuse of power through intimidation, in terms of interfering with investigations and hostility toward investigators is an important finding. This kind of aggressive behavior is strategically used to create feelings of fear, in order to avoid accountability and perhaps future investigations.

\section{Professional: Failure of Responsibility}

Failure to fulfill responsibility referred to employees not carrying out assigned enforcement of control mechanisms duties/obligations and was another factor that explained NCAA violations. Corruption is likely to occur in organizations when the "official rules and control systems are not enforced" (Frost \& Tischer, 2014, p. 200) because of either the difficulty in monitoring and/or laissez-faire approach to com- 
pliance. In the NCAA context, strict compliance control mechanisms are instituted. However, rule violations occurred because individuals neglected their responsibility to implement them (e.g., not engaging in rules compliance, not accurately documenting and reporting activities, and not communicating compliance expectations). For example, head coaches improperly monitored staff in terms of inspecting documentation of recruiting practices (e.g., monitoring text messages or phone calls, prospective student-athlete observations and tryouts) or practice activities (e.g., number of hours, summer workouts). Compliance directors failed to routinely review or cross check coaches' recruiting, practice, and eligibility documentation logs unless something "looked suspicious" (Case \#11). Failure to enforce control mechanisms was also found when organizational leaders (coaches, compliance staff, and athletic director) ignored a possible violation, and/or did not report a possible or actual violation. A number of cases described that despite leaders possessing "knowledge about a potential situation" (e.g., a relationship, fraud) the individual "made no effort to interview" the respective parties to determine if a violation had occurred (e.g., Cases $\# 4,10,11,13)$.

In multiple cases, compliance directors neglected to deliver adequate NCAA rules education, which ultimately manifested into institutional actors' lack of knowledge of the rules and/or a misinterpretation of rules influencing corruption. NCAA rules education and understanding the meaning and intent of the rules is a compliance director's main responsibility, yet numerous instances were reported where institutional personnel (coaches, admissions and financial aid staff, compliance staff) were unaware of the rules, did not understand the rules (e.g., eligible coaches, impermissible benefits, recruiting) and as a result misinterpreted the rules. The following quotation represents this theme, "the head coach had a responsibility to familiarize herself with NCAA legislation regarding playing and practice season activities and also had an obligation to ask questions of the institution's athletics compliance officer regarding the application of NCAA regulations" (Case \#7). Respective actors' failures to provide oversight - documentation and reporting — and compliance education illustrates the role of power in creating corrupt practices. Leaders dictate the behavioral expectations within an organization and enable corrupt practices through not suitably educating stakeholders, "enforcing or circumventing rules and controls" (Frost \& Tischer, 2014, p. 200).

\section{Justifications: Rationalization}

Individual rationalizations justifying corrupt decisions and/or behaviors as acceptable or the right thing to do was the final theme. Rationalizations involved neutralizing strategies where corrupt acts were downplayed, the seriousness minimized, or characterized as insignificant. For example, neutralizing strategies used included "if a violation occurred, it was only secondary" (Case \#12), "my back is turned, I didn't see it" (Case \#2), and "the $\$ 200$ offer for the student-athlete to play through the cramps was a "joke"- I didn't mean it" (\#17). Neutralizing justifications for engaging in corrupt acts also involved humanitarian justifications where individuals were attempting to promote human welfare such as providing student-athletes impermis- 
sible benefits for travel to visit a sick relative or to be present for a childbirth (e.g., Case \#12). Several cases involved rationalizing aiding international student-athletes such as a "head coach described his motive as humanitarian, helping the family (by giving them $\$ 6,000$ ) of a prospect in war-torn Serbia" (Case \#4). Another case reported a compliance officer weighing the options in deciding whether to provide travel for an athlete so he could safely renew his visa. "My options, I felt that was the, not the best, but of all the options certainly, again, I'd rather be guilty of an extra benefit violation than have a kid being sent home in a box from getting shot at the border" (Case \#9). Individuals typically do not engage in or perceive themselves as corrupt (Ashford \& Anand, 2003), through rationalizing ideologies such as downplaying the magnitude of the act and moral justification of helping people in need actors in this study believed they were acting ethically. Bandura et al. (2000, p. 57) state "detrimental conduct is made personally and socially acceptable by portraying it in the service of valued social and moral purposes". In this study, rationalizations were guised under humanitarian causes because for example, "the prospect had no other transportation available and he needed a ride to complete a course exam." However, in many of these cases, the underlying motivation was a rational choice to promote one's self-interest (e.g., eligibility).

\section{Summary and Implications}

This study aimed at gaining an understanding of factors that contributed to intercollegiate athletic actors' decisions to engage in corruption; and subsequently based on the multi-case analysis generate an interdisciplinary framework conceptualizing the influencing factors. Figure 1 presents such a framework that included themes that represent psychology, economics, and organizational management. To date, no empirical study has generated a context specific interdisciplinary framework that identified concepts for explaining actors' decisions to engage in corrupt behavior in sport. Zaloznaya' (2014) definition of corruption underpins the framework-Corruption is context dependent and individuals' interactions with the rules system and the social environment influence their decisions to commit corruption. The framework proposes that intercollegiate athletic actors make sense of the NCAA rules through the legislative system where they gain an understanding of normative behavioral expectations. The decision to engage in corruption is based on three interrelated influencing factors: 1) psychological (motivations (social relationship and self-interest) and personal norms), 2) professional (abuse of power and failure of responsibilities), and 3) justifications (rationalizing strategies). From a psychological perspective, athletic department actors were motivated to break the rules due to different social relationships (e.g., personal, professional, and third party) and self interest (desire to win, gain a competitive advnatge, material gain, and athlete eligiblity). Personal norms influenced actors to engage in corruption as they intentionally disregarded upholding the rules. The psychological factors suggest that individuals belonging to social networks, whose self-interests are focused on matieral gain and winning, and have weak personal norms possess stronger tendancies to act corrupt (Gorsira et al., 
2016). These psychological factors underlie professional influencing factors of abuse of power by using directives, concealment, and intimidation to commit corrupt acts. Actors also failed in their professional responsibility as they neglected to monitor, investigate, and/or provide rules education. An individual's personal norms influences whether they believe it is acceptable to abuse their power and/or the extent that they should carryout their role responsibilities. Lastly, individuals justify corrupt behaviors by rationalizing (i.e., minimizing and promoting human welfare) the behavior as acceptable organizational conduct. Justifications are related to actors' motivations, personal norms and professional behaviors. Motivations and personal norms underpin the nature of actors' justifications (e.g., minimizing the serious of the violation or using humanitarian reasons). Actors' rule breaking behaviors are morally justified by arguing the activities were personally and socially acceptable because they were minor infrigements and helped people in need. Future research examining how rationalizing strategies evolve and become normalized within a group and/or organization could enhance our understanding of how these potent types of justifying behaviors are accepted by intercollegiate actors.

Given the unique context of intercollegiate athletics, the framework provides a starting point that allows for a more suitable assessment of the underlying influencers that lead to corrupt behaviors that may not be relevant in other sport contexts (e.g., professional sport or international sport federations). Based on the findings, one would be remiss to assume that the examination of malfeasance in intercollegiate athletics can appropriately be conducted from a single discipline and/or theoretical lens. Future research could explore if additional explanations of sport corruption exist in different organizational contexts and by integrating interdisciplinary perspectives.

The creation of an interdisciplinary framework of individual-level explanations of corruption within intercollegaite athletics distinguished this study from prior sport corruption studies (e.g., Cullen et al., 2012; Engelberg et al., 2015; Hill, 2009a ; Lee, 2017), and in particular in the context of intercollegiate athletics. The multi-case analysis showed that three forms of corruption (i.e., fraud, bribery, and unethical conduct) and their respective types (e.g., academic fraud, impermissible recruiting inducements, and failure to cooperate) occurred across varying institutions and sports. Of note, NCAA corruption was carried out by a wide range of actors, across many sports, and not solely by revenue sport coaches and players. The intercollegiate athletic context demonstrated interrelated explanations of engaging in corruption that has yet to be theorized and/or empirically examined in other sport contexts thus highlighting the importance and contribution of generating a theoretical framework to assist in analyzing NCAA corruption. For example, department actors lacked problem awareness - weak personal norms - that was demonstrated through their blatant rule violations, abuse of power, and failure to fulfill their responsibilities. Intercollegiate athletic actors also used rationalizing and neutralizing techniques related to humanitarian justifications. Although humanitarian justifications mirror Anand et al. (2004) "appealing to higher loyalties" rationalizing technique, in the intercollegiate athletic context actors' altruistic justifications for committing 


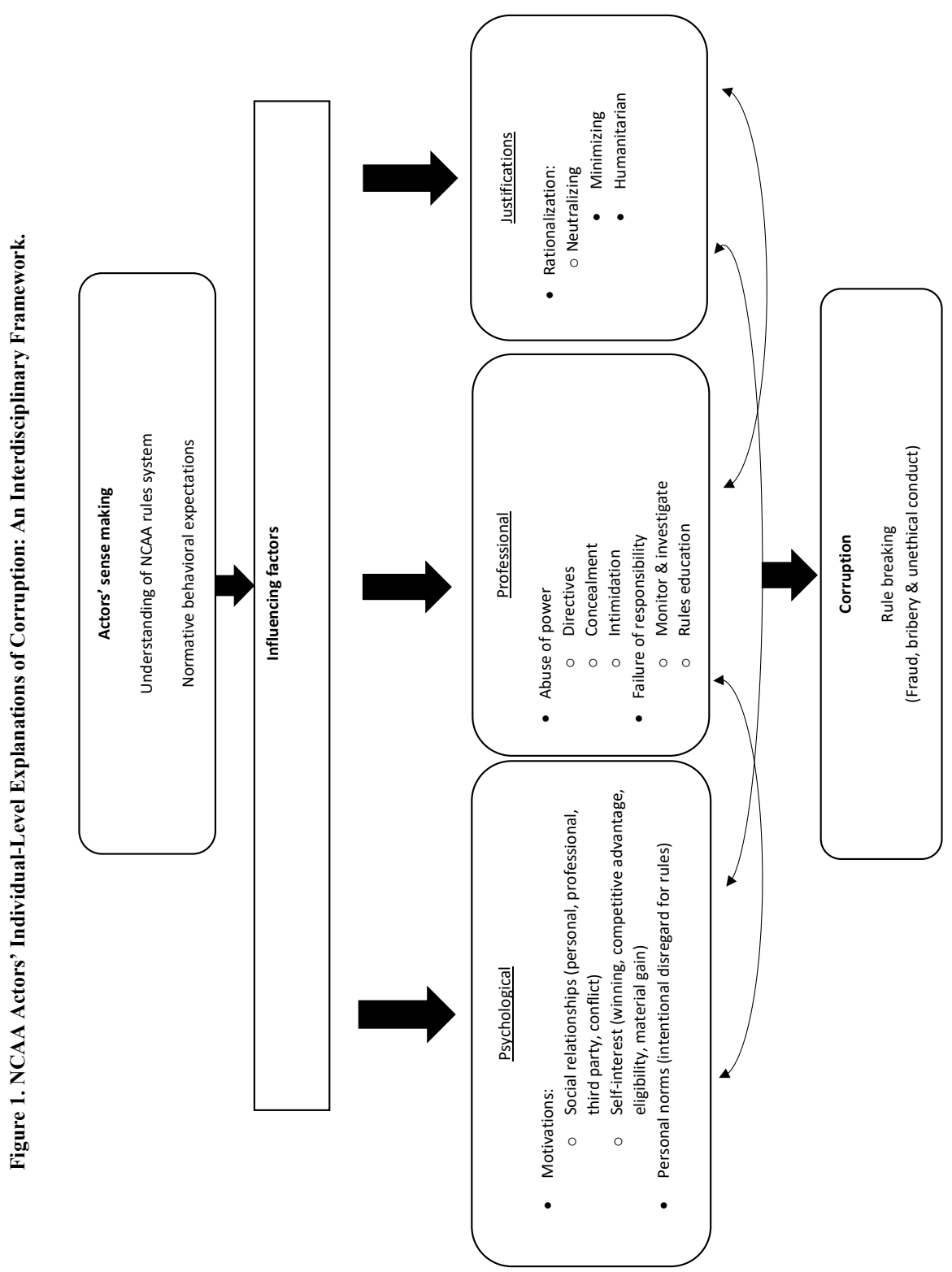


corruption involved both sincere and disingenuous reasons. Intercollegiate athletic administrators need to be vigilant and question these weak personal norms and reject rationalizing and neutralizing techniques.

Two main practical implications for intercollegiate athletic leaders are evident. First, anti-corruption interventions should incorporate micro-level causes of corruption within the education and compliance systems. To enhance current compliance education and reduce rules violations, it is imperative that administrators understand why individuals engage in corruption. As noted, few studies have investigated causes of rule violations from a multi-case analysis. This study uncovered a variety of interrelated factors explaining athletic department stakeholders corrupt behaviors beyond a cost-benefit analysis. Targeting social relationships, personal norms, abuses of power, and rationalizing strategies might assist with compliance rather than past practices of increasing regulation, which by and large is the anti-corruption strategy of choice. Education and compliance programs should target these root sources of corruption, as identified in this study. Gaining insight into the underlying sources of corruption is important for improving current compliance programs and practices and reducing corrupt behaviors.

Second, despite the NCAA's extensive compliance education and enforcement practices instituted by member institutions, corruption is a persistent feature. The compliance system is based on an integrity model that seeks for members to uphold the values of intercollegiate athletics (National Collegiate Athletic Association, 2016) in creating and fostering a culture of integrity. While this strategy is commendable, it fails to fundamentally address individuals who work within a strong culture and receive rules education, yet blatantly disregard the rules and commit corruption. The NCAA's integrity approach to compliance assumes that individuals with weak personal norms will change their moral values when placed in an organizational culture of integrity, which is inconsistently supported in the literature (e.g., Coombs, 1998). This begs the question of how can sport organizations keep from hiring individuals who possess weak personal norms. Requiring integrity tests (e.g., measurements of irresponsibility, carelessness violation of rules) to all applicants is a strategy that could assist administrators in preventing hiring individuals who are more than likely to engage in corruption (Kish-Gephart et al., 2010; Ones, Viswesvaran, \& Schmidt, 1993). However, such a strategy requires athletic department leaders possessing the moral courage to hire people with integrity and resisting pressure to hire individuals who have questionable integrity.

\section{Limitations}

The findings of this study should be considered in light of its limitations, which may offer future research opportunities. First, the findings were based on a crosscase analysis, therefore, conclusions regarding causality cannot not be drawn. The strength of multiple-case sampling is adding confidence to the findings through examining the range of similar and contrasting cases to establish how, where, and 
where possible, why a phenomenon occurred (Miles et al., 2014). However, it cannot be deciphered if all five themes (motivations, personal norms, abuse of power, failure of responsibility and rationalization) directly contributed to actors' decisions to engage in rule violations in this study. Experimental research could also test to determine the causality of the five factors with corrupt behaviors in intercollegiates. Second, although the study examined factors contributing to NCAA sport actors' decisions to engage in corruption, individual roles and responsibilities associated with each actor might have also been an influencing factor. Future research could examine athletic department actors' roles and responsibilities to potentially expand on the framework of individual-level explanations of NCAA corruption. Third, despite the detailed NCAA reports, multiple data sources (e.g., interviews, surveys) could have also enhanced the breadth and depth of data collected and expanded on the interdisciplinary framework concepts. Gaining access to this type of data is extremely challenging because corrupt actors are either reluctant to participate and/or provide accurate information (Bell et al., 2017; Engelberg et al., 2015).

In conclusion, this study presented a framework outlining individual-level explanations of corruption in the context of intercollegiate athletics where it was argued that to enhance our understanding of why actors engage in sport corruption requires an interdisciplinary approach. The findings contribute to understanding micro-level causes of sport corruption by showing that psychological and professional factors in conjunction with varying justifications contributed to athletic department actors engaging in corruption. Sport administrators and leaders should consider these individual-level explanations in revised compliance education and reform strategies.

\section{References}

Ashford, B. E., \& Anand, V. (2003). The normalization of corruption in organizations. Research in Organizational Behavior, 25, 1-52

Anand, V., Ashforth, B. E., \& Joshi, M. (2004). Business as usual: The acceptance and perpetuation of corruption in organizations. The Academy of Management Executive, 18, 39-53.

Andvig, J.C., \& Fjeldstad, O.H. (2001). Corruption a review of contemporary research: Report. Oslo, Norway: Norsk Utenrikspolitisk Institut.

Bag, P. K., \& Saha, B. (2011). Match-fixing under competitive odds. Games and Economic Behavior, 73, 318-344.

Balsdon, E., Fong, L., \& Thayer, M. A. (2007). Corruption in college basketball? Evidence of tanking in postseason conference tournaments. Journal of Sports Economics, 8, 19-38.

Bandura, A. (1999). Moral disengagement in the perpetration of inhumanities. Personality and Social Psychology Review, 3, 193-209.

Bandura, A. (2002). Selective moral disengagement in the exercise of moral agency. Journal of Moral Education, 31, 101-119.

Bandura, A., Caprara, G. V., \& Zsolnai, L. (2000). Corporate transgressions through moral disengagement. Journal of Human Values, 6, 57-64. 
Bell, P., Dean, G., Vakhitova, Z., \& Ranley, J. (2018). Research methods. In L. A. Kihl (Ed.) Corruption in sport: Causes, consequences and reform. (pp. 173199). London, UK: Routledge.

Bell, P., Ten Have, C., \& Lauchs, M. (2016). A case study analysis of a sophisticated sports doping network: Lance Armstrong and the USPS Team. International Journal of Law, Crime and Justice, 46, 57-68.

Blau, P. M. (1964). Exchange and power in social life. New York: Wiley.

Boardley, I. D., \& Kavussanu, M. (2011). Moral disengagement in sport. International Review of Sport and Exercise Psychology, 4(2), 93-108.

Boeri, T., \& Severgnini, B. (2011). Match rigging and the career concerns of referees. Labour Economics, 18, 349-359.

Brass, D. J., Butterfield, K. D., \& Skaggs, B. C. (1998). Relationships and unethical behavior: a social network perspective. Academy of Management Review, 23, 14-31.

Bricknell, S. (2015). Corruption in Australian sport. Trends and Issues in Crime and Criminal Justice, 490, 1-11.

Caiden, G.E., Dwivedi, O.P., and Jabbra, J. (2001). Introduction. In G. E. Caiden, O. P. Dwivedi and J. Jabbra, J. (eds). Where corruption lives. (pp. 1-14). Bloomfield, CT: Kumarian Press.

Carpenter, K. (2012). Match-fixing-The biggest threat to sport in the 21 st Century? Int Sports Law Rev, 2, 13-23.

Clark, R. S., \& Batista, P. J. (2009). Whitepaper Summary: Do BCS national championships lead to recruiting violations? A trend analysis of NCAA division I (FBS) infractions. Journal of Sport Administration and Supervision, 1. Retrieved from http://hdl.handle.net/2027/spo.6776111.0001.105

Collins, J. D., Uhlenbruck, K., \& Rodriguez, P. (2009). Why firms engage in corruption: A top management perspective. Journal of Business Ethics, 87, 89-108.

Coombs, J. R. (1998). Educational ethics: Are we on the right track? Educational Theory, 48(4), 555-569.

Cullen, F. T., Latessa, E. J., \& Jonson, C. L. (2012). Assessing the extent and sources of NCAA rule infractions. Criminology \& Public Policy, 11, 667-706.

Davis, T. (1999). Sports law in the 21st century: Intercollegiate athletics in the next millennium, a framework for evaluating reform proposals. Marquette Sports Law Journal, 9, 1-20.

De Graff, G. (2009). Causes of corruption: Towards a contextual theory of corruption. Public Administration Quarterly, 31, 39- 86

Ehrnborg, C., \& Rosén, T. (2009). The psychology behind doping in sport. Growth Hormone \& IGF Research, 19, 285-287.

Eisenhardt, K. M. (1989). Building theories from case study research. Academy of Management

Review, 14, 532-550.

Engelberg, T., Moston, S., \& Skinner, J. (2015). The final frontier of anti-doping: A study of athletes who have committed doping violations. Sport Management Review, 18, 268-279. 
Fizel, J., \& Brown, C. A. (2014). Assessing the determinants of NCAA football violations. Atlantic Economic Journal, 42, 277-290.

Feustel, E. D., \& Rodenberg, R. M. (2015). Sports (betting) integrity: Detecting match-fixing in soccer. Gaming Law Review and Economics, 19, 689-694.

Forrest, D., McHale, I., \& McAuley, K. (2008). "Say It Ain't So": Betting-related malpractice in sport. International Journal of Sport Finance, 3, 156-166.

Frost, J., \& Tischer, S. (2014). Unmasking collective corruption: The dynamics of corrupt routines. European Management Review, 11, 191-207.

Gorse, S., \& Chadwick, S. (2010). Conceptualising corruption in sport: Implications for sponsorship programmes. The European Business Review, 4, 40-45. Retrieved from http://www.europeanbusinessreview.com/?p=1973

Gorsira, M., Denkers, A., \& Huisman, W. (2016). Both sides of the coin: Motives for corruption among public officials and business employees. Journal of Business Ethics, 1-16. doi.org/10.1007/s10551-016-3219-2

Granovetter, M. S. (1973). The strength of weak ties. American Journal of Sociology, 78, 1360-1380.

Hill, D. (2009a). How gambling corruptors fix football matches. European Sport Management Quarterly, 9, 411-432.

Hill, D. (2009b). To fix or not to fix? How corruptors decide to fix football matches. Global Crime, 10, 157-177.

Hill, D. (2010). A critical mass of corruption: Why some football leagues have more match-fixing than others. International Journal of Sports Marketing and Sponsorship, 11, 38-52.

Hill, D. (2013). The insider's guide to match-fixing in football. Toronto, ON: Anne McDermid \& Associates Ltd.

Hill, D. (2015). Jumping into fixing. Trends in Organized Crime, 18, 212-228.

Humphreys, B. R. (2012). NCAA rule infractions. Criminology \& Public Policy, 11, 707-712.

INTERPOL. (2017). Match-fixing and illegal gambling. Retrieved from https://www. interpol.int/Crime-areas/Crimes-in-sport/Match-fixing-and-illegal-gambling

Jancsics, D. (2014). Interdisciplinary perspectives on corruption. Sociology Compass, 8 , 358-372.

KEA. (2012). Match-fixing in sport: A mapping of the criminal law provisions in EU 27. KEA European Affairs, Brussels. Retrieved from http://ec.europa.eu/sport/ library/studies/study-sports-fraud-final-version_en.pdf.

Kihl, L. A., Ndiaye, M., \& Fink, J. (2018). Corruption's impact on organizational outcomes. Social Responsibility Journal, 14(1), 40-60.

Kihl, L. A., \& Richardson, T. (2009). "Fixing the mess": A grounded theory of a men's basketball coaching staff's suffering as a result of academic corruption. Journal of Sport Management, 23, 278-304.

Lincoln, Y. S., \& Guba, E. G. (1985). Naturalistic inquiry. Thousand Oaks, CA: Sage

Kirby, K., Moran, A., \& Guerin, S. (2011). A qualitative analysis of the experiences of elite athletes who have admitted to doping for performance enhancement. International Journal of Sport Policy and Politics, 3, 205-224. 
Kish-Gephart, J. J., Harrison, D. A., and Treviño, L. K. (2010). Bad apples, bad cases, and bad barrels: meta-analytic evidence about sources of unethical decisions at work. Journal of Applied Sport Psychology, 95, 1-31.

Langseth, P. (2016). Measuring corruption. In C. Sampford, A Shacklock, C. Connors, \& F. Galtung (eds.), Measuring corruption. (pp. 23-60). London, UK: Routledge.

Lastra, R., Bell, P., \& Bond, C. (in press). Sports betting and the integrity of Australian sport: Athletes' and non-athletes' perceptions of betting-motivated corruption in sport. International Journal of Law, Crime and Justice, DOI 10.1016/j. ijlcj.2017.11.005

Lee, P. C. (2017). Understanding the match-fixing scandals of professional baseball in Taiwan: an exploratory study of a Confucianism-oriented society. European Sport Management Quarterly, 17, 45-66.

Lentillon-Kaestner, V., \& Carstairs, C. (2010). Doping use among young elite cyclists: A qualitative psychosociological approach. Scandinavian Journal of Medicine \& Science in Sports, 20, 336-345.

Lopinao, D. (2016). The roots of corruption in US collegiate sport. In Transparency International's Global corruption report: Sport. (pp. 275-285). London, UK: Routledge.

Maennig, W. (2005). Corruption in international sports and sport management: Forms, tendencies, extent and countermeasures. European Sport Management Quarterly, 5, 187-225.

Maennig, W. (2008). Corruption in international sports and how it may be combatted. International Association of Sports Economists \& North American Association of Sports Economists, Working Paper Series, 08-13. Retrieved from http:// college.holycross.edu/RePEc/spe/Maennig_Corruption.pdf

Manoli, A. E., \& Antonopoulos, G. A. (2015). The only game in town? Football match-fixing in Greece. Trends in Organized Crime, 18, 196-211.

Marshall, C., \& Rossman, G. B. (2014). Designing qualitative research. (6 ${ }^{\text {th }}$ ed.). Thousand Oaks, CA: Sage publications.

Masters, A. (2015). Corruption in sport: From the playing field to the field of policy. Policy and Society, 34, 111-123.

Maxwell, J. A. (2013). Qualitative Research Design: An Interactive Approach. Thousand Oaks, CA: Sage Publications.

Miles, M. B., Huberman, M. A., \& Saldana, J. (2014). Drawing and verifying conclusions. Qualitative data analysis: A methods sourcebook. Thousand Oaks, CA: Sage Publications.

Moore, C., Detert, J. R., Trevino, K., Baker, V. L., \& Mayer, D. M. (2012). Why employees do bad things: moral disengagement and unethical organizational behavior. Personnel Psychology, 65, 1-48.

National Collegiate Athletics Association. (2016). Legislative Services DatabaseLSDBi. National Collegiate Athletic Association. Retrieved from https://web1. ncaa.org/LSDBi/exec/miSearch 
National collegiate Athletic Association. (2018). Committee on sportsmanship and ethical conduct. Retrieved from http:/www.ncaa.org/governance/committees/ committee-sportsmanship-and-ethical-conduct.

Nassif, N. (2014). Corruption in sport: the case of Lebanon. Middle East Law and Governance, 6, 123-140.

Nixon, H. L. (2014). The athletic trap: How college sports corrupted the academy. Baltimore, MD: JHU Press.

Numerato, D. (2015). Corruption and public secrecy: An ethnography of football match-fixing. Current Sociology, 64, 699-717.

Ones, D. S., Viswesvaran, C., \& Schmidt, F. L. (1993). Comprehensive meta-analysis of integrity test validities: Findings and implications for personnel selection and theories of job performance. Journal of Applied Psychology, 78(4), 679-703.

Palmer, D. (2012). Normal organizational wrongdoing: A critical analysis of theories of misconduct in and by organizations. Oxford, UK: Oxford University Press.

Pappa, E., \& Kennedy, E. (2013). It was my thought... he made it a reality: Normalization and responsibility in athletes' accounts of performance-enhancing drug use. International Review for the Sociology of Sport, 48, 277-294.

Paoli, L., \& Donati, A. (2014). The sports doping market: Understanding supply and demand and the challenges of their control. New York: Springer.

Patton, M.Q. (2002). Qualitative evaluation and research methods. Newbury Park, CA: Sage.

Pertiwi, K. (2018). Contextualizing corruption: A cross-disciplinary approach to studying corruption in organizations. Administrative Sciences, 8, 1-19.

Peurala, J. (2013). Match-manipulation in football-the challenges faced in Finland. The International Sports Law Journal, 13, 268-286.

Ridpath, B. D., Gurney, G., \& Snyder, E. (2015). NCAA academic fraud cases and historical consistency: A comparative content analysis. J. Legal Aspects Sport, 25, 75-103.

Schwartz, S. H., \& Howard, J. A. (1981). A normative decision-making model of altruism. A normative decision-making model of altruism. In J. P. Rushton and R. M. Sorrentino (Eds.), Altruism and helping behavior (pp. 189-211). Hillsdale, NJ: Lawrence Erlbaum.

Scientific Software Development. (2016). ATLAS ti: The knowledge workbench visual qualitative data analysis management model building (Version 7). Berlin, Germany: Scientific Software Development.

Spapens, T., \& Olfers, M. (2015). Match-fixing: The current discussion in Europe and the case of the Netherlands. European Journal of Crime, Criminal Law and Criminal Justice, 23, 333-358.

Steg, L., \& Groot, J. (2010). Explaining prosocial intentions: Testing causal relationships in the norm activation model. British Journal of Social Psychology, 49, 725-743.

Stake, R. E. (1994). Case studies. In N. K. Denzin and Y. S. Lincoln (eds.) Handbook of qualitative research, (pp. 236-24). Thousand Oaks: Sage. 
Stake, R. E. (1995). The art of case study research. Thousand Oaks, CA: Sage Publications.

Wainstein, K. L., Jay, A. J., \& Kukowski, C. D. (October 16, 2014). Investigation of irregular classes in the Department of African and Afro-American Studies at the University of North Carolina at Chapel Hill. New York: Cadwalader

Yost, M. (2009). Varsity green: A behind the scenes look at culture and corruption in college athletics. Stanford, CA: Stanford University Press.

Zaloznaya, M. (2014). The social psychology of corruption: Why it does not exist and why it should. Sociology Compass, 8, 187-202.

Zimbalist, A. (2018). Whither the NCAA: Reforming the system. Review of Industrial Organization, 52(2), 337-350.

Zyglidopoulos, S. C., Fleming, P. J., \& Rothenberg, S. (2009). Rationalization, overcompensation and the escalation of corruption in organizations. Journal of Business Ethics, 84 (Suppl.1), 65-73. 